


\section{Measurement of Structural Response}

\section{Characteristics of Full-Scale Buildings:}

\section{Selection of Structures}

R. D. Marshall

Long T. Phan

M. Celebi*

*Branch of Engineering Seismology and Geology

U.S. Geological Survey

Menlo Park, CA

February 1991

\section{U.S. Department of Commerce}

Robert A. Mosbacher, Secretary

National Institute of Standards and Technology

John W. Lyons, Director

Building and Fire Research Laboratory

Gaithersburg, MD 20899 


\section{ABSTRACT}

This report describes the selection of existing building structures for subsequent field measurements of low-level ambient vibrations. By comparing measurement results with previously recorded highlevel responses, it is anticipated that guidance can be developed for improved measurement practice. The buildings selected for this effort represent a cross-section of contemporary structural systems and materials, foundation types, and a range of building heights and aspect ratios. Each building was subjected to strong shaking during the Loma Prieta Earthquake of October 17, 1989.

Keywords: buildings, earthquake, instrumentation, dynamic response, field measurements, structural dynamics 
TABLE OF CONTENTS

\begin{abstract}
• . . . . . . . . . . . . . . . . . . . . . . . i i

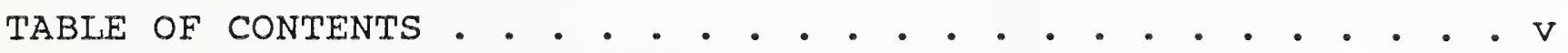

INTRODUCTION

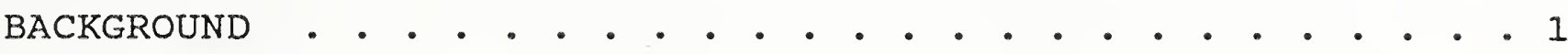

TEST PROGRAM • • • . . . . . . . . . . . . • . . . . . 2

CANDIDATE STRUCTURES • • • • • • • • • • • • • • • • • • 2

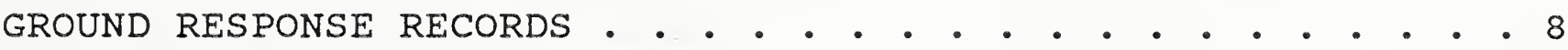

STRUCTURAL RESPONSE DATA • . . . . . . . . . . . . . . . . 13

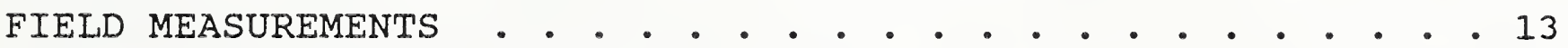

ACKNOWLEDGMENTS • • • • • • • • • • • • • • • • • • • • 15

REFERENCES • • • • • • • • • • • • • • • • • • • • • •
\end{abstract}


$v i$ 


\section{INTRODUCTION}

This report presents a summary description of building structures in the San Francisco Bay area that have been selected for use in a study of dynamic characteristics. Specifically, the validity of small-amplitude testing methods for the assessment of dynamic characteristics will be studied. Each of the buildings described herein was instrumented with strong-motion accelerometers prior to the Loma Prieta Earthquake of October 17, 1989 ( $\left.\mathrm{M}_{\mathrm{s}}=7.1\right)$ and yielded excellent sets of response records during the earthquake. The buildings have been selected to cover a range of structural systems, construction materials, aspect ratios, and foundation types.

\section{BACKGROUND}

Reliable estimates of modal frequencies, stiffness and damping of structural systems are essential for predicting the dynamic response under loading conditions associated with serviceability or structural safety. Although response characteristics of isolated structural components usually can be predicted with acceptable accuracy using simple models, this is not the case for complete structures where primary and secondary systems can interact in complex ways. Examples of such interaction include the participation of cladding in overall system stiffness and damping, the participation of infill walls and non-structural partition walls, and the interaction of floor systems with columns and bearing walls.

Analytical models for calculating building response usually involve substantial simplification of the real structure and, for various reasons, detailed physical scale models for controlled testing in the laboratory often prove impractical. Consequently, each of these approaches must depend on reliable full-scale field measurements for validation and/or improvement of the modeling technique. Changes in the dynamic properties of structures subjected to strong seismic excitation are related to the intensity and extent of damage and, therefore, reliable full-scale response measurements are of potential use in the assessment of structural damage.

Numerous studies of structural response have been carried out on tall buildings, long-span bridges, and large dams. The most widely used technique has been to rely on ambient vibrations for excitation or, in certain cases, to use one or more mechanical shakers to excite specific modes of vibration in the structure. In rare cases response measurements have been obtained during extreme events such as earthquakes or wind storms. Generally, these measurements suggest a strong dependence of response parameters on displacement amplitude, thus raising questions about the validity and proper interpretation of response measurements obtained under 
low levels of excitation. It is not unknown for seemingly identical structures to exhibit basic characteristics such as stiffness that differ by as much as 50 percent (Ellis and Littler, 1987). In the case of structural damping, determinations may differ by a factor of two or more. How much of this disparity can be attributed to actual physical differences and how much can be attributed to measurement errors and incorrect interpretation of test results is unknown.

\section{TEST PROGRAM}

The Loma Prieta Earthquake of October 17, 1989, provided a unique opportunity to carry out a program of field measurements and analytical modeling of a select number of existing structures to better understand the significance of factors such as displacement amplitude in full-scale response measurements. In particular, it should be possible to interpret characteristics measured under lowlevel response in the light of known (recorded) high-level response. The approach will be to select a number of undamaged buildings that were subjected to strong ground shaking during the Loam Prieta Earthquake and for which valid response records are available. It should be possible from these records to obtain estimates of overall damping, the first two or three modal frequencies and the peak accelerations and displacements.

Existing analytical models can be used to estimate transverse and torsional modes of vibration and to predict response to low-level excitation. These predicted responses can then be used as a basis for selecting and installing suitable instrumentation with which to conduct low-level response measurements. To the extent possible, instrumentation systems installed in the buildings at the time of the Loma Prieta Earthquake will be utilized in the field measurement program.

\section{CANDIDATE STRUCTURES}

Buildings that are considered to be good candidates for additional study are listed in Table 1 and are located on the local area map of Figure 1. This map also indicates the major ground failures caused by the Loma Prieta Earthquake. The instrumentation systems in these candidate structures were installed and are maintained by the United States Geological Survey (USGS) and by the California Division of Mines and Geology (CDMG). The structural systems include steel frames, reinforced concrete moment frames and combinations of the two. No attempt has been made to include shear-wall systems in the selection although some of the structural systems include shear wall or core walls in the lower stories of the structure. The data included in Table 1 were extracted from post-earthquake reports by Maley et al., 1989, and by Shakal et al., 1989. Photographs of the buildings are included in Figures 26. 


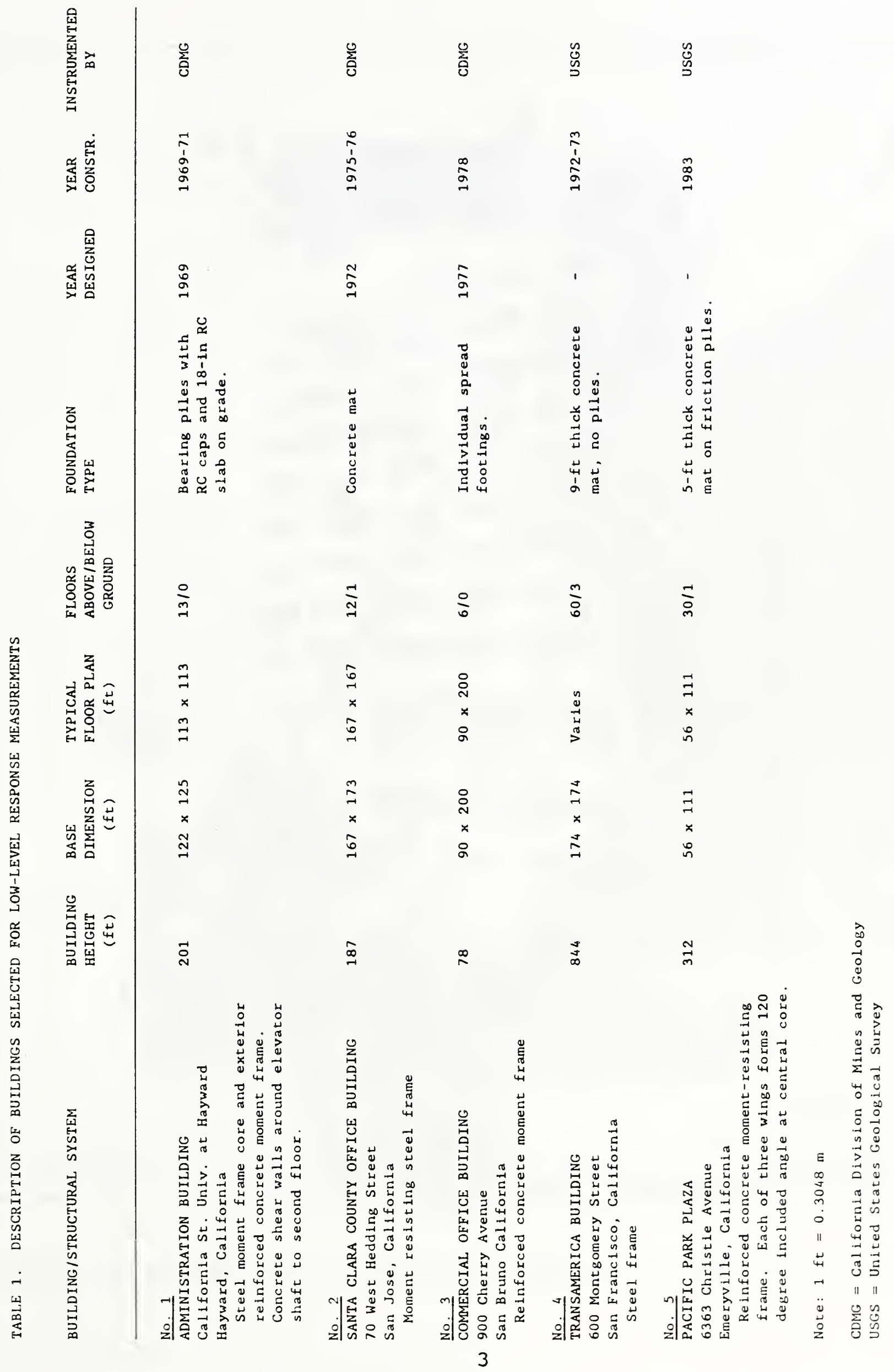




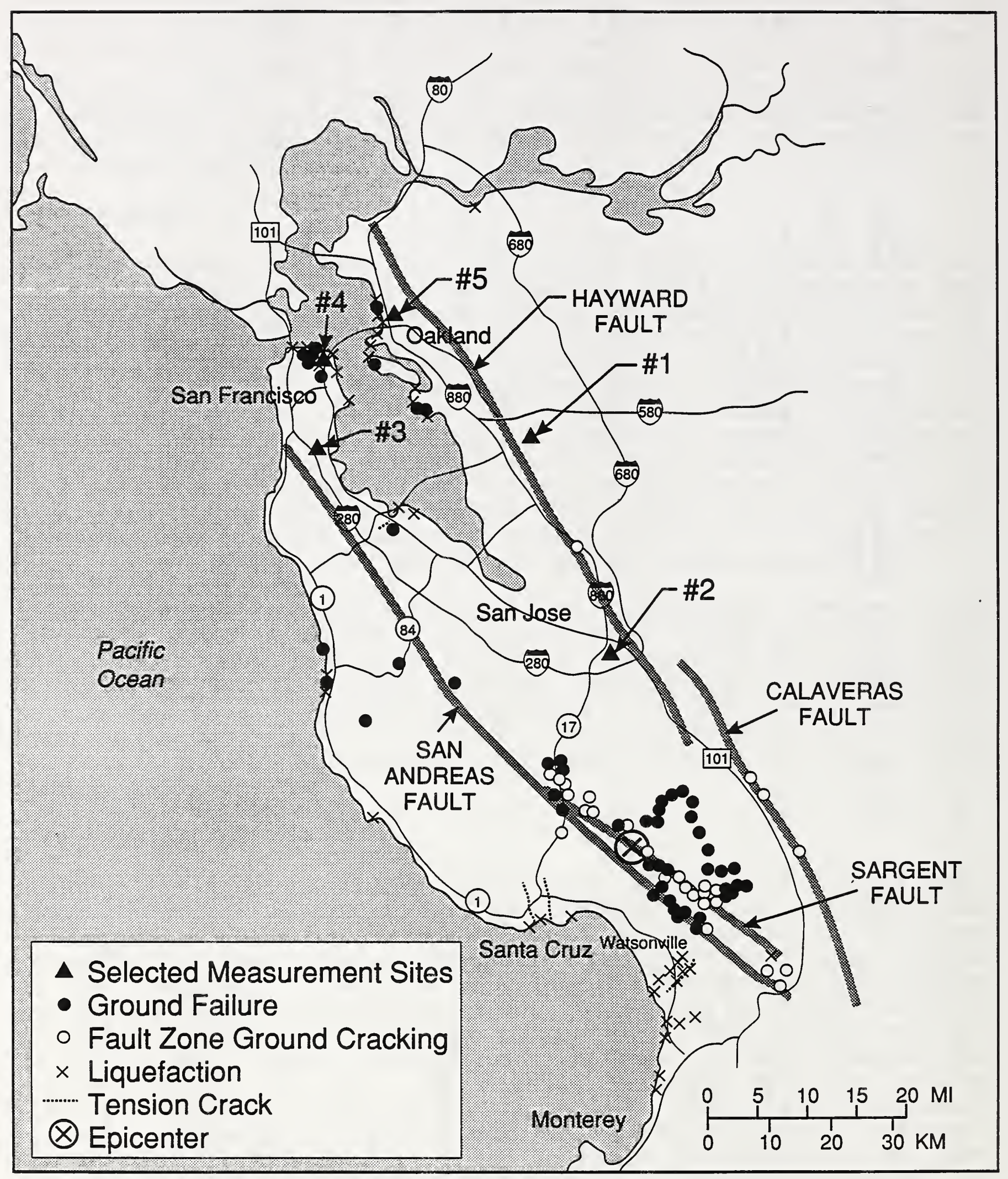

Figure 1: Locations of Selected Measurement Sites and Major Faults. 


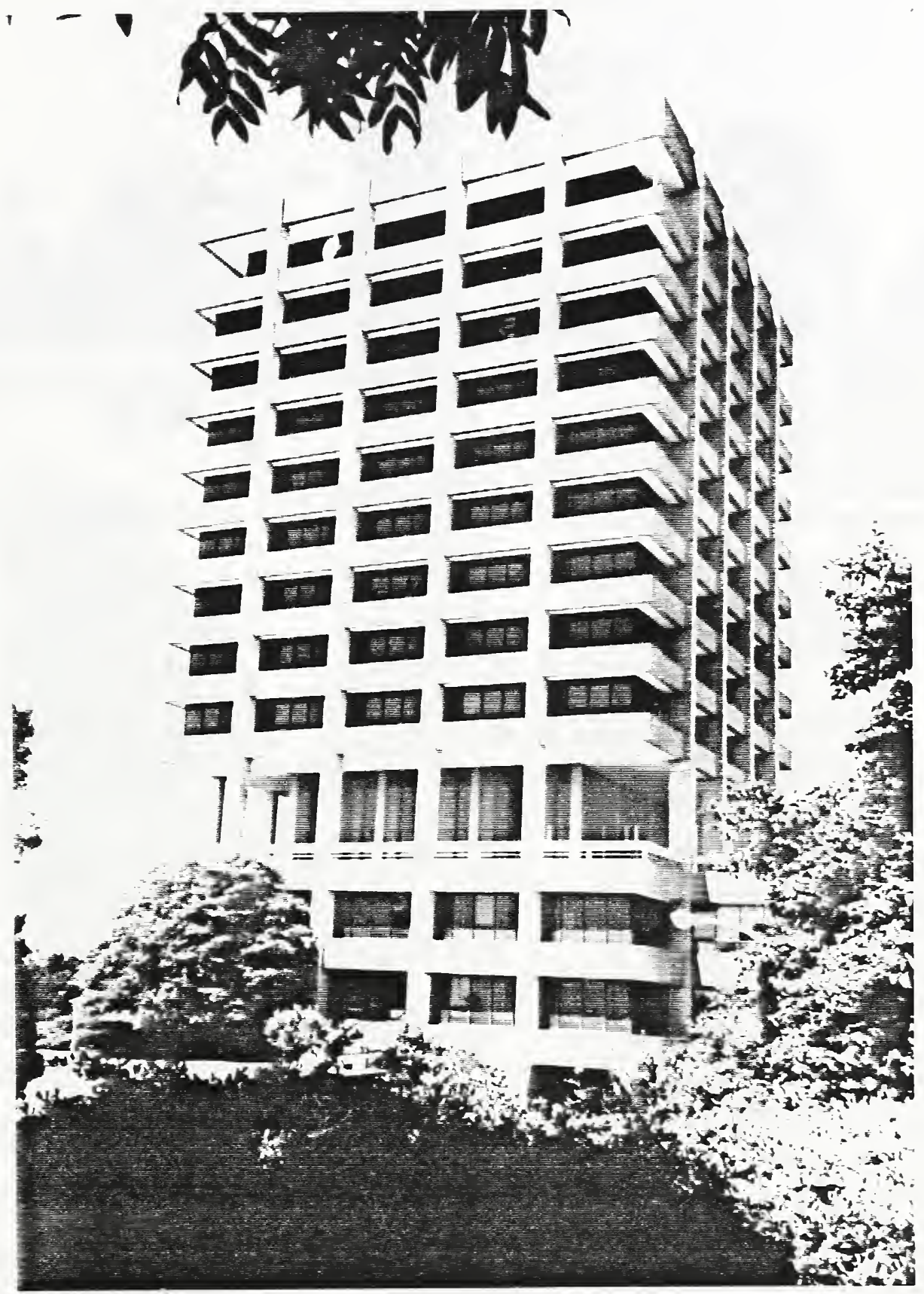

Figure 2: Administration Building, CSUH, Hayward. view to northwest. 


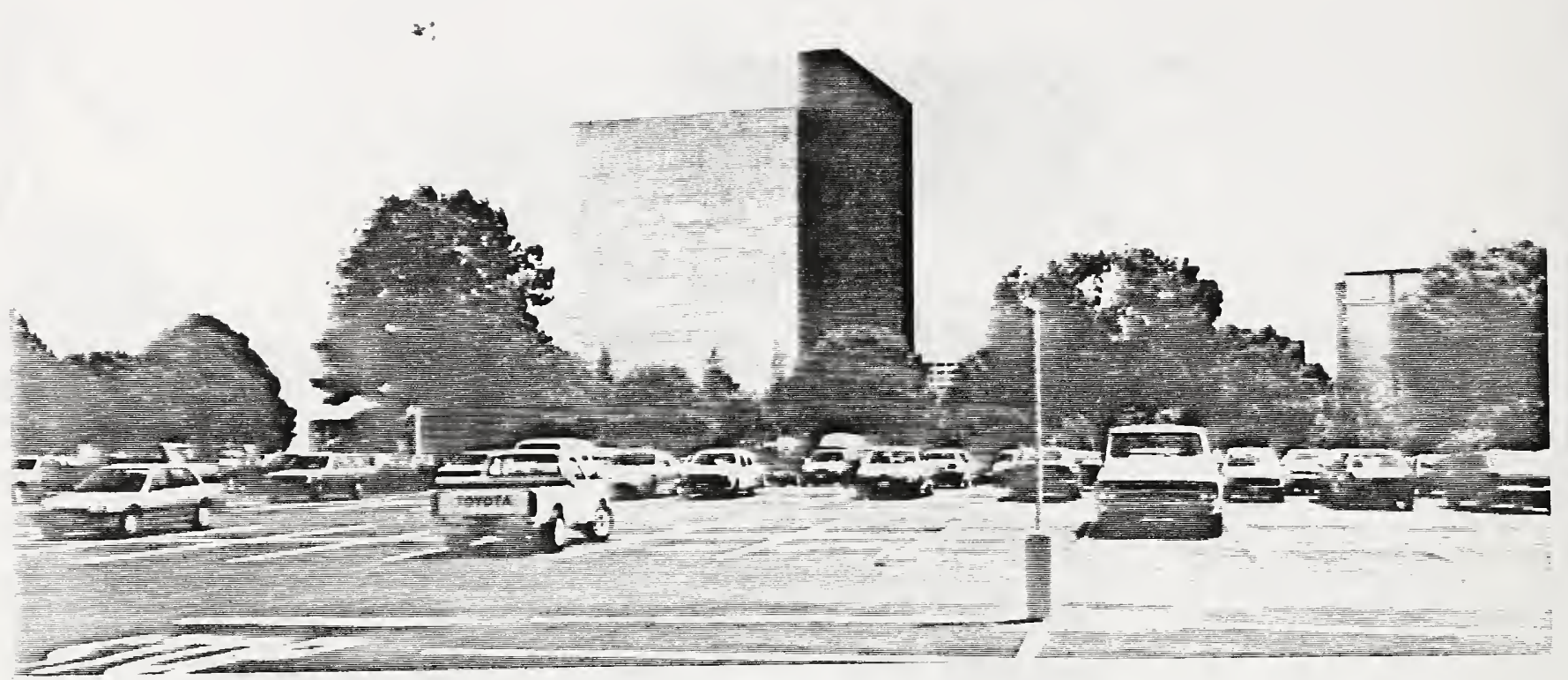

Figure 3: Santa Clara county office Building, san Jose. view to southeast.

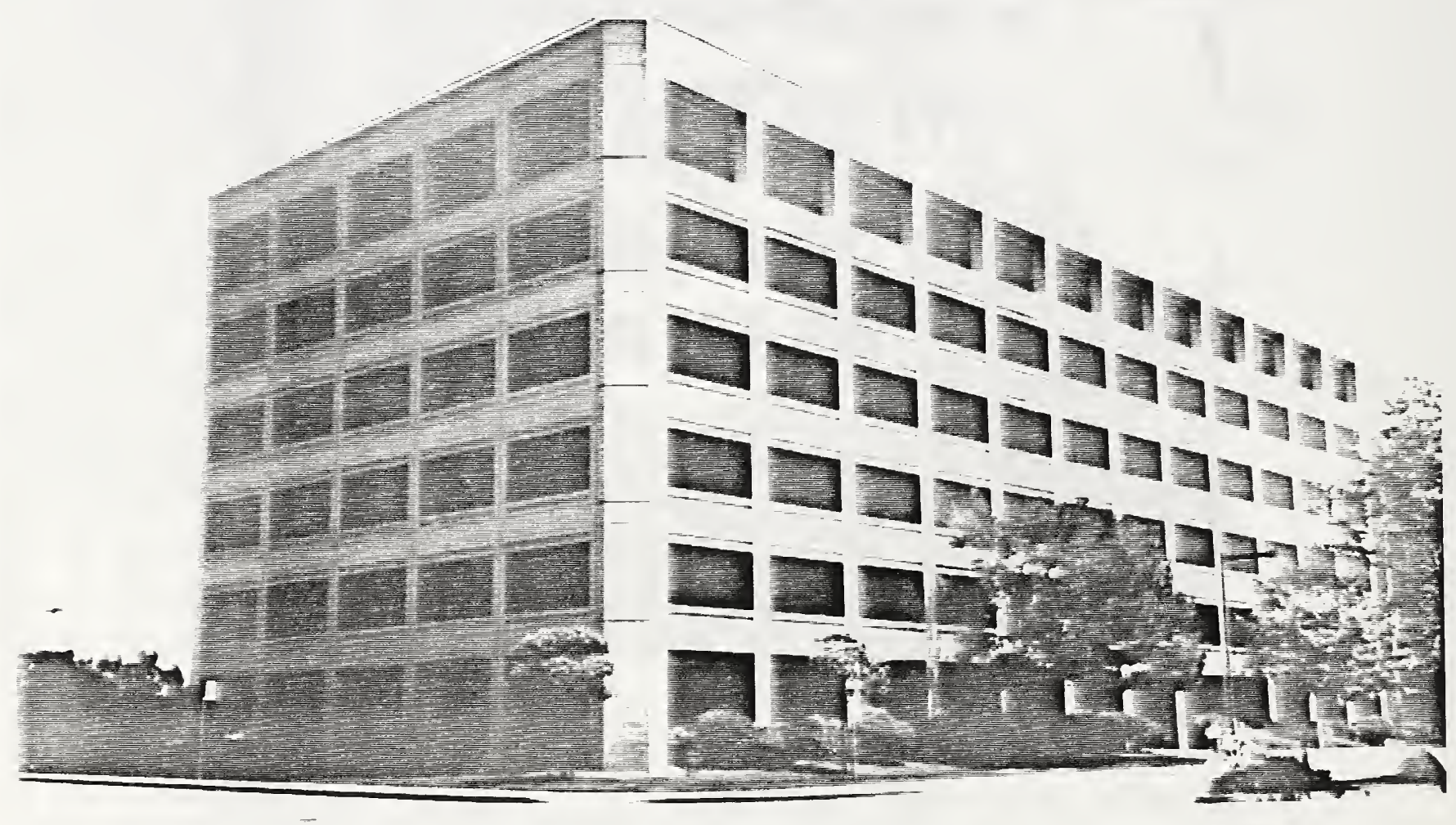

Figure 4: Commercial office Building, san Bruno. View to southeast 


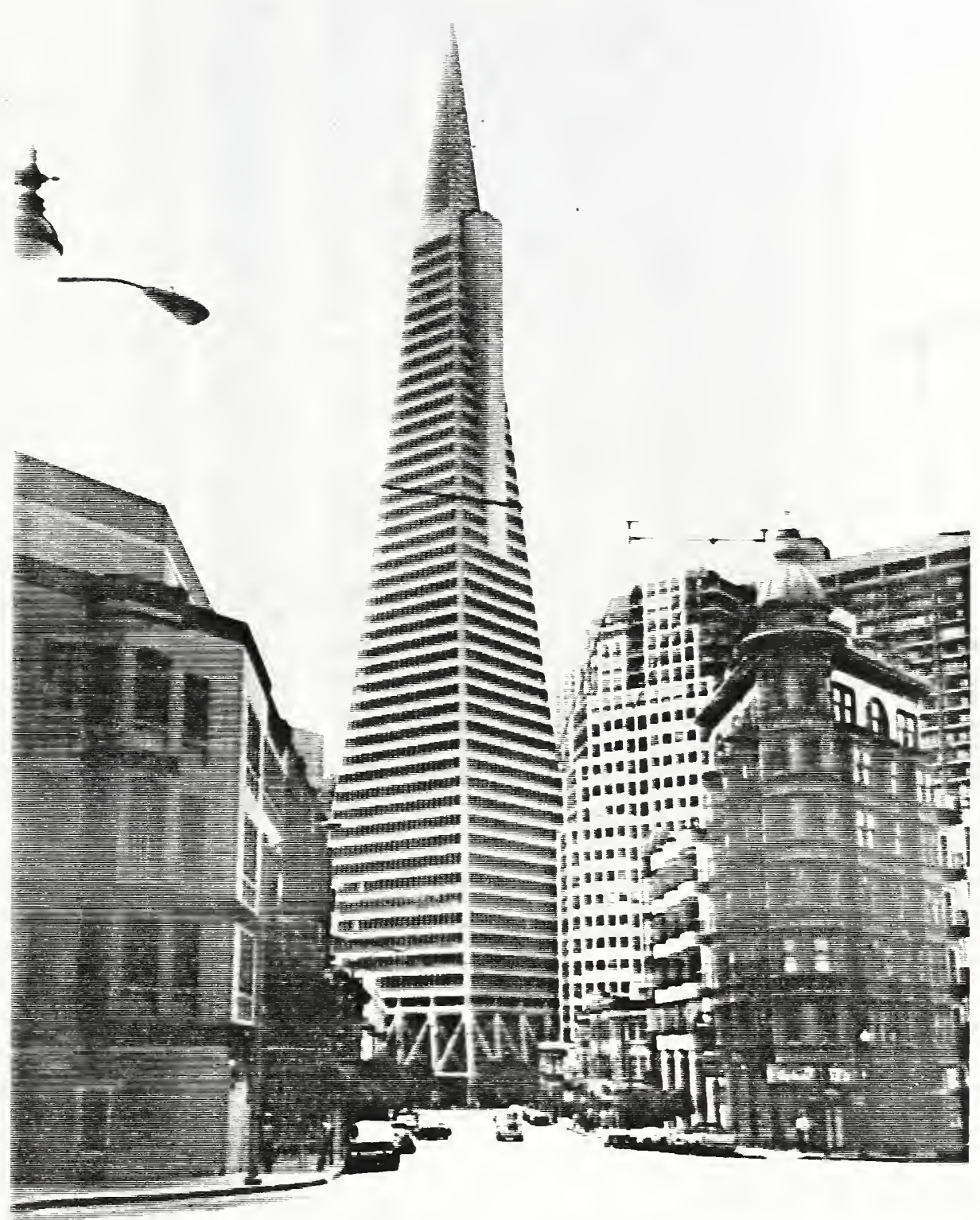

Figure 5: Transamerica Building, San Francisco. View to southeast. 


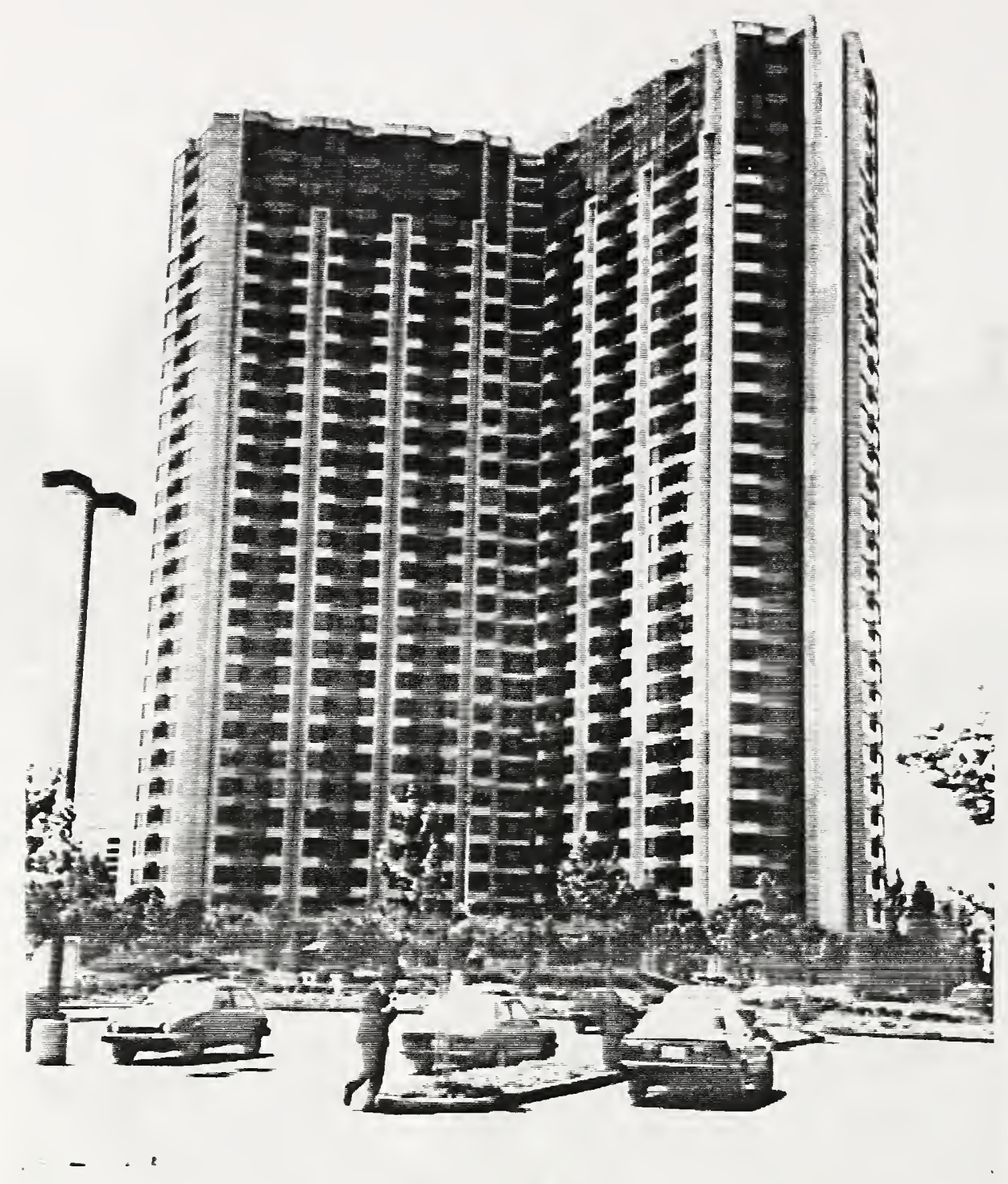

Figure 6: Pacific Park Plaza, Emeryville. View to west.

\section{GROUND RESPONSE RECORDS}

Table 2 contains a summary of peak ground accelerations at basement level in each of the five selected buildings and at strong-motion sites in the vicinity of the selected buildings. In most cases the sites represent free-field conditions, not being affected significantly by nearby buildings or other structures. In some cases the instrumentation is either in or adjacent to a singlestory building such as a fire house. For the Transamerica Building in San Francisco, the strong-motion sites at Diamond Heights, Pacific Heights and Telegraph Hill are located within two-story buildings. 
TABIE 2. SUMMARY OF LOMA PRIETA GROUND RESPONSE RECORDS AT OR NEAR BUILDINGS SELECTED FOR ADDITIONAL STUDY

STATION NAME

\section{EPICENTRAL \\ DISTANCE}

$(\mathrm{km})$
ACCELERATION COMPONENTS

(g)
ADMINISTRATION BUILDING - CSUH

N. Lat. $=37.655$

W. Long. $=122.056$

Site Geology: Franciscan metavolcanic rock

Fremont - Mission San Jose

N. Lat. $=37.530$

W. Long. $=121.919$

Site Geology: Alluvium

Hayward - CSUH Stadium Grounds

N. Lat. $=37.657$

W. Long. $=122.061$

Site Geology: Franciscan greenstone

Hayward - Muir School

N. Lat. $=37.657$

W. Long. $=122.082$

site Geology: Alluvium

Hayward - BART Station Parking Lot

N. Lat. $=37.670$

W. Long. $=122.086$

Site Geology: Alluvium

SANTA CLARA COUNTY OFFICE BUILDING

N. Lat. $=37.353$

W. Long. $=121.903$

Site Geology: Alluvium

San Jose - Santa Teresa Hills

N. Lat. $=37.210$

W. Long. $=121.803$

Site Geology: Alluvium over serpentine

Saratoga - Aloha Avenue

N. Lat. $=37.255$

W. Long. $=122.031$

Site Geology: Alluvium
27

70

55

71

71

73

35

21

$225=0.28$
$U p=0.22$
$315=0.27$

$\mathrm{Up}=0.10$

$337=0.11$

$090=0.14$

$\mathrm{Up}=0.10$

$360=0.18$

$310=0.16$

$\mathrm{Up}=0.08$

$220=0.16$

$\mathrm{Up}=0.05$
320.05

$320=0.08$

$090=0.11$

$\mathrm{Up}=0.09$

$090=0.08$

$\mathrm{Up}=0.05$

$360=0.08$$$
220=0.16
$$

5

$090=0.34$

$\mathrm{Up}=0.41$

$360=0.53$ 
(Table 2 continued)

STATION NAME

EPICENTRAL

DISTANCE

$(\mathrm{km})$
ACCELERATION COMPONENTS

(g)
San Jose Interchange - 101/280/680

$\mathrm{N}$. Lat. $=37.340$

W. Long. $=121.851$

site Geology: Not available

Halls Valley - Grant Park

N. Lat. $=37.338$

W. Long. $=121.714$

Site Geology: Alluvium

Agnew - Agnew state Hospital

N. Lat. $=37.239$

W. Long. $=121.952$

site Geology: Alluvium

Sunnyvale - Colton Avenue

N. Lat. $=37.402$

W. Long. $=122.024$

site Geology: Not available

OFFICE BUILDING - SAN BRUNO

N. Lat. $=37.628$

W. Long. $=122.424$

Site Geology: Alluvium

Upper Crystal springs Reservoir

(Skyline Blvd.)

$\mathrm{N}$. Lat. $=37.465$

W. Long. $=122.343$

Site Geology: Sandstone

Upper Crystal Springs Reservoir (Pulgas Water Temple)

N. Lat. $=37.49$

W. Long. $=122.31$

Site Geology: Sandstone

Foster City - Redwood Shores

N. Lat. $=37.55$

W. Long. $=122.23$

Site Geology: Alluvium to $210 \mathrm{~m}$, serpentine
34

$232=0.13$

$\mathrm{Up}=0.08$

$322=0.18$

37

$090=0.11$

$\mathrm{Up}=0.06$

$360=0.13$

40

$090=0.16$

$\mathrm{Up}=0.10$

$360=0.17$

43

$270=0.19$

$\mathrm{Up}=0.10$

$360=0.22$

81

$245=0.12$

$\mathrm{Up}=0.12$

$335=0.14$

63

$090=0.09$

$\mathrm{Up}=0.04$

$360=0.10$

63

$090=0.09$

$\mathrm{Up}=0.06$

$360=0.16$

63

$090=0.29$

$\mathrm{Up}=0.11$

$360=0.26$ 
(Table 2 continued)

STATION NAME

EPICENTRAL

DISTANCE

$(\mathrm{km})$
ACCELERATION COMPONENTS

(g)
San Francisco International Airport

N. Lat. $=37.622$

W. Long. $=122.398$

Site Geology: Deep alluvium

79

$090=0.33$

$\mathrm{Up}=0.05$

$360=0.24$

South San Francisco - Sierra Point

N. Lat. $=37.674$

W. Long. $=122.388$

Site Geology: Not available

TRANSAMERICA BUILDING

N. Lat. $=37.80$

W. Long. $=122.40$

Site Geology: Not available

San Francisco - Golden Gate Bridge

N. Lat. $=37.806$

W. Long. $=122.472$

Site Geology: Not available

San Francisco - Presidio

N. Lat. $=37.792$

W. Long. $=122.457$

Site Geology: Serpentine

San Francisco - Diamond Hts.

N. Lat. $=37.74$

W. Long. $=122.43$

Site Geology: Franciscan chert

San Francisco - Pacific Hts.

N. Lat. $=37.79$

$\mathrm{W}$. Long. $=122.43$

Site Geology: Franciscan sandstone, shale

San Francisco - Telegraph Hill

$\mathrm{N}$. Lat. $=37.80$

W. Long. $=122.41$

Site Geology: Franciscan shale, sandstone
97

100

98

92

97

97
$083=0.12$

$\mathrm{Up}=0.07$

$351=0.11$

$270=0.24$

$\mathrm{Up}=0.06$

$360=0.12$

$090=0.21$

$\mathrm{Up}=0.06$

$360=0.10$

$090=0.12$

$\mathrm{Up}=0.05$

$360=0.10$

$270=0.06$

$\mathrm{Up}=0.03$

$360=0.05$

$090=0.08$

$\mathrm{Up}=0.03$

$360=0.06$ 
(Table 2 continued)

San Francisco - Rincon Hill

$\mathrm{N}$. Lat. $=37.79$

w. Long. $=122.39$

Site Geology: Franciscan sandstone, shale

Yerba Buena Island

N. Lat. $=37.81$

W. Long. $=122.36$

Site Geology: Franciscan sandstone

Treasure Island

N. Lat. $=37.825$

W. Long. $=122.373$

Site Geology: Fill

PACIFIC PARK PLAZA - EMERYVILLE

N. Lat. $=37.844$

W. Long. $=122.295$

Site Geology: Silty fine sand fill and Bay mud on hard silty clay

Pacific Park Plaza

Free Field - South

Pacific Park Plaza

Free Field - North

Piedmont - Piedmont Jr. High Grounds

N. Lat. $=37.823$

W. Long. $=122.233$

Site Geology: Weathered serpentinite

Berkeley - UCB Memorial stadium Grnds. 98

N. Lat. $=37.87$

W. Long. $=122.25$

Site Geology: Not available

Berkeley, U.C. - Strawberry Canyon

N. Lat. $=37.87$

$\mathrm{W}$. Long. $=122.24$

Site Geology: Not available
95

95

$090=0.09$

$\mathrm{Up}=0.03$

$360=0.08$

98

$090=0.16$

$\mathrm{Up}=0.02$

$360=0.11$

$080=0.21$

$\mathrm{Up}=0.06$

$350=0.17$

$090=0.26$

$\mathrm{Up}=0.06$

$360=0.22$

97

$090=0.22$

$\mathrm{Up}=0.09$

$360=0.20$

$045=0.08$

$\mathrm{Up}=0.03$

$315=0.07$

$135=0.13$

$\mathrm{Up}=0.03$

$225=0.07$

98

$135=0.04$

$\mathrm{Up}=0.02$

$045=0.08$ 
(Table 2 continued)

STATION NAME

EPICENTRAL

ACCELERATION

DISTANCE

$(\mathrm{km})$

COMPONENTS

(g)

Berkeley - Lawrence Berkeley Lab

99

$090=0.12$
$U p=0.04$
$360=0.05$

N. Lat. $=37.876$

W. Long. $=122.249$

Site Geology: Thin alluvium on shale, siltstone

Richmond - 2501 Rydin Road

101

$057=0.08$

N. Lat. $=37.884$

$\mathrm{Up}=0.04$

W. Long. $=122.302$

$327=0.11$

Site Geology: Not available

Richmond - city Hall Parking Lot

108

$280=0.11$
$U p=0.04$
$190=0.13$

w. Long $=122.342$

Site Geology: Alluvium

STRUCTURAL RESPONSE DATA

Representative structural response data obtained during the Loma Prieta Earthquake are listed in Table 3. A considerable amount of response data from these and other structures has not yet been processed or analyzed. Also included in Table 3 are selected results of forced vibration studies carried out prior to Loma Prieta and measurements of ambient vibrations carried out by USGS and NIST personnel on May 10-11, 1990.

\section{FIELD MEASUREMENTS}

To the extent possible, use will be made of the permanently installed instrumentation in the candidate structures. The advantages of this approach are that it allows a direct comparison of low-level measurements with high-level measurements and considerably reduces the amount of time and effort required to carry out the field measurements. The major disadvantage is that the sensitivities of the permanently installed sensors may in certain cases be too low to obtain reliable acceleration measurements. In most cases the permanently installed sensors are force-balance accelerometers (FBA's) with a nominal sensitivity of 2.5 volts $/ g$ and a resolution of approximately 1 micro-g. If necessary, additional point measurements can be obtained using portable accelerometers provided by USGS.

The NIST data acquisition system to be used in the field measurement program has an input range of \pm 10 volts and employs 


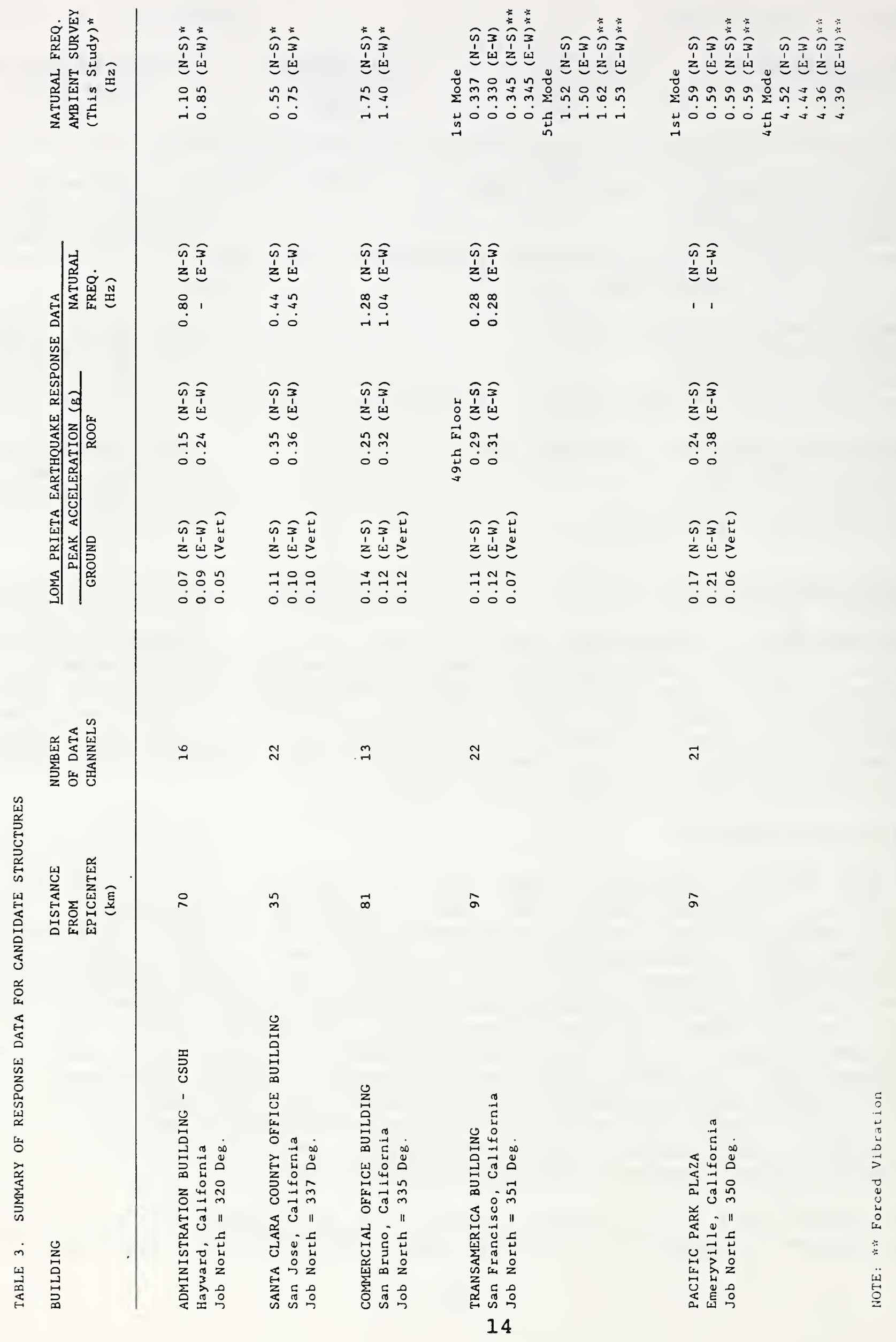


a 12-bit A/D converter capable of performing up to 250,000 conversions per second. A total of 16 data channels can be multiplexed at the 250,000/sec rate. Each data channel is provided with a differential input amplifier, a 3-pole active filter, and a sample-and-hold amplifier. Thus the samples obtained in each scan of the data channels have zero time skew. The differential amplifiers have nine jumper-selectible gains covering the range $\mathrm{xl}$ to $\mathrm{x} 500$. If desired, DC components in the amplified signal can be nulled with a programmable offset voltage of up to 40 percent of the dynamic range. The effective dynamic range of the data acquisition system is extended by a programmable-gain amplifier in the $A / D$ section with a gain selection of $1,2,4$, or 8 . The filter type and cutoff frequency can be changed by changing resistor and capacitor networks on the signal conditioning cards. The configuration to be used in this measurement program is a Butterworth low-pass filter with a cutoff frequency of $10 \mathrm{~Hz}$. The sample rate will be 50 samples per second per channel. The minimum record length will be 2,048 samples or approximately 40 seconds. It is anticipated that several minutes of recordings will be collected at each field site.

\section{ACKNOWLEDGMENTS}

The authors wish to acknowledge the assistance of Dr. M. J. Huang, Office of strong Motion Studies, California Division of Mines and Geology, who provided valuable information on structural systems and Loma Prieta response data for the field sites. Mr. Marion Salsman, Branch of Engineering Seismology and Geology, U.S. Geological survey, provided valuable assistance in conducting the field measurements.

\section{REFERENCES}

1. Celebi, M., et al. (1985). "Integrated Instrumentation Plan for Assessing the Seismic Response of Structures - A Review of the Current USGS Program." U.S. Geological Survey Circular 947 , 1985, 38 pages.

2. Celebi, M. and Safak, E. (1990). "Recorded Seismic Response of Transamerica Building. Part I - Data and Preliminary Analysis." Paper submitted to ASCE Journal of structural Engineering, 1990.

3. Ellis, B.R. and Littler, J.D. (1987). "Lessons From Dynamic Testing of Buildings." Structural Assessment, F. Garas et al. Eds., Butterworths, London, 1987, pp 63-70.

4. Maley, R., et al. (1989). "U.S. Geological survey strongMotion Records From the Northern California (Loma Prieta) Earthquake of October 17, 1989." Geological Survey Open-File Report 89-568, October 1989, 85 pages. 
5. Shakal, A.F., et al. (1989). "CSMIP Strong-Motion Records From the Santa Cruz Mountains (Loma Prieta), California Earthquake of October 17, 1989." Report No. OSM 89-03, November 1989. 


\begin{tabular}{|c|c|c|}
\hline \multirow{4}{*}{$\begin{array}{l}\text { NIST-114A } \\
\text { (REV. 3-90) }\end{array}$} & \multirow{2}{*}{$\begin{array}{l}\text { U.S. DEPARTMENT OF COMMERCE } \\
\text { NATIONAL INSTITUTE OF STANDARDS AND TECHNOLOGY }\end{array}$} & $\begin{array}{l}\text { 1. PUBUCATION OA REPORT NUMBEA } \\
\text { NISTIR } 4511\end{array}$ \\
\hline & & PEAFORMINO OAGAMIZATION AEPOAT NUMBER \\
\hline & \multirow[t]{2}{*}{ BIBLIOGRAPHIC DATA SHEET } & 3. PUBLICATION DATE \\
\hline & & February 1991 \\
\hline
\end{tabular}

4. TITLE AND SUBTITLE

Measurement of Structural Response Characteristics of Full-Scale Buildings: Selection of structures

5. AUTHOR(S)

Richard D. Marshall, Long T. Phan, M. Celebi

6. PEAFORMIMO ORGAMIZATION (IF JOINT OR OTHER THAN NIST, SEE INSTRUCTIONS)

U.S. DEPARTMENT OF COMMERCE

NATIONAL INSTITUTE OF STANDARDS AND TECHNOLOOY

CANTHERSBURQ, MD 20890

7. CONTRACT/GRANT NUMBER

8. TYPE OF REPORT AND PEAIOD COVERED

9. SPONSORING ORGANIZATION MAME AND COMPLETE ADDAESS (STREET, CTT, STATE ZP)

10. SUPPLEMENTARY NOTES

11. ABSTAACT (A 200-WOAD OA LESS FACTUAL SUMMARY OF MOST SIOMIFICANT IMFOAMATION. IF DOCUMENT INCLUDES A SIGMIFICANT BIBLOGRAPHY OA UTERATURE SURVEY, MENTION IT HERE.)

This report describes the selection of existing building structures for subsequent field measurements of low-level ambient vibrations. By comparing measurement results with previously recorded high-level responses, it is anticipated that guidance can be developed for improved measurement practice. The buildings selected for this effort represent a cross-section of contemporary structural systems and materials, foundation types, and a range of building heights and aspect ratios. Each building was subjected to strong shaking during the Loma Prieta Earthquake of October 17, 1989.

12. KEY WOROS (6 TO 12 ENTRIES; ALPHABETICAL ORDER; CAPITALZE ONLY PROPER NAMES; AND SEPARATE KEY WORDS BY SEMICOLONS)

buildings, earthquake, instrumentation, dynamic response, field measurements, structural dynamics

13. AVAILABILTY

UNUMITED

FOR OFFICLAL OISTRIBUTION. OO NOT RELEASE TO NATIOMAL TECHMICAL INFORMATION SERVCE (NTIS).

ORDER FROM SUPERINTENDENT OF DOCUMENTS, U.S. GOVERMMENT PRIMTIMG OFFICE, WASHIMOTON, DC 20402.

ORDER FROM NATIOMAL TECHMICAL INFORMATION SERVICE (NTIS), SPRIMGFIELO, VA 22161.

\begin{tabular}{|} 
14. NUMBER OF PRINTED PAQES \\
24 \\
\hline 15. PRICE \\
AO2 2 \\
\hline
\end{tabular}



. 
